\title{
Physical changes of low quality of clay bricks due to sandy- soil mixture under combustion performance
}

\author{
Muhammad Ridwan ${ }^{1}$, Ade Indra $^{3}$, Annisa Febiana Yunera ${ }^{1}$, and Rudy Kurniawan ${ }^{2 *}$ \\ ${ }^{1}$ Department of Civil Engineering, Faculty of Engineering, Padang Institute of Technology, West Sumatera, Indonesia \\ ${ }^{2}$ Department of Civil Engineering, Faculty of Engineering, Andalas University, West Sumatera, Indonesia \\ ${ }^{3}$ Department of Mechanical Engineering, Faculty of Engineering, Padang Institute of Technology, West Sumatera, Indonesia
}

\begin{abstract}
This research studies the physical properties of the low quality of bricks mixed with sandy -soil in home industries located in Gunung Sarik of Padang City. The ratio mixture of the brick making material in the home industries was not measured with the proper measurement; as a result the quality of the brick was poor. The research used $5 \times 5 \times 5 \mathrm{~cm}$ and 180 cubes of bricks to see the physical changes. The ratio of mixed materials between sandy soil and clay are $0.11 .025,0.43,0.67,1.0$, and 1.50. The procedure for making bricks was the same as a factory without changing the factory method. The process of burning bricks for three days and two nights using wood. From the test results, the density of the bricks did not change significantly between direct and indirect fire exposure but decreased in proportion to the addition of sandy soil. The addition of sandy soil reduces the percentage of damage and physical changes. The acceptable ratio of sandy -soil mixture is a range of 0.43.-0.6.
\end{abstract}

\section{Introduction}

Limestone West Sumatra is one of the province in Indonesia that is prone to earthquakes [1]. However, more than $80 \%$ of either residence or office buildings used bricks which are produced do not meet the Indonesian Industrial Standard (SNI) of 15-2094-2000.

Most of brick manufacturers in West Sumatra are home industries which are operated traditionally. They use sandy sand soil as the primary material to be mixed with clay. However, they do not have any standard amount of each material for the mixture. In other word, the portion of the material in each brick could be varied.

Some manufacturers use wood in the burning process of the bricks. Using wood in the process will allow more heat absorption in order to produce a good quality of the bricks. The ideal heat temperature in this process is in range of 800-1000 ${ }^{\circ} \mathrm{C}$. However, they fail to have that range of temperature although having put the bricks close to the wood fire. [4].

Bricks are a mixture of sand (silica) and clay (alumina) mixed with a predetermined composition and added with water to become plasticity. In the making process the bricks should be easily printed, dried without shrinkage and produced without any cracks or curves. Investigating the physical changes in the making process of the bricks have been conducted by several researchers $[1,2,3]$.

Producing strong bricks must use a good quality of clay which is added with other materials [5]. The location where the clay is excavated determines the quality of the clay itself [6]. Having a proper heat and fuel in the combustion also contributes greatly to the strength of the bricks. The properties of bricks depend on the nature of each brick unit, the quality of the raw materials used, and the technology in the manufacturing process. Therefore, it is essential to obtain information about the bricks' physical, chemical, and mechanical feasibility, the raw materials' characteristics, and the manufacturing process. Brick making initially often used a mixture of $30 \%$ sand and $70 \%$ clay [6]

This study examined the bricks produced by manufacturers in Gunung Sarik and find out how the changes of bricks that had been studied previously with materials and positions in different combustion processes. The similar making process was used in the production of the bricks. However, the material and combustion position were different. For this study, composition of sand and clay were at ratios of $0.11 .025,0.43,0.67,1.0$, and 1.50. The burning process used firewood and was carried out with the brick position close to the fire and far from the fire. The distance of the fire was around \pm 20 $\mathrm{cm}$. It was expected that it could improve the quality and quantity which met the SNI 15-2094-2000. Then it could be a guideline for improving the method of making bricks in the home industries of West Sumatra

\section{Clay Brick}

* Corresponding author: ruddykurniawan@eng.unand.ac.id 
According to SNI 15-2094-2000, a brick is a building or construction material made of a mixture of clay and other materials heated in high temperature.

According to the Indonesian Industrial Standard (SII0021-1978), the compressive strength of clay bricks is divided into six strength classes. Table 1 shows the average compressive strength of bricks.

Table 1. The average compressive strength of bricks (SII-0021-78)

\begin{tabular}{|c|r|r|r|}
\hline \multirow{2}{*}{ Class } & \multicolumn{2}{|c|}{$\boldsymbol{f}^{\prime}$} & \multicolumn{1}{c|}{$\begin{array}{c}\text { Permit } \\
\text { coefficient of } \\
\text { variation }\end{array}$} \\
\cline { 2 - 3 } & $\mathbf{K g} / \mathbf{c m}^{\mathbf{2}}$ & \multicolumn{1}{|c|}{$\mathbf{N} / \mathbf{m m}^{2}$} & $25 \%$ \\
\hline 25 & 25 & 2,5 & $22 \%$ \\
\hline 50 & 50 & 5 & $22 \%$ \\
\hline 100 & 100 & 10 & $15 \%$ \\
\hline 150 & 150 & 15 & $15 \%$ \\
\hline 200 & 200 & 20 & $15 \%$ \\
\hline 250 & 250 & 25 & \\
\hline
\end{tabular}

According to SNI 15-2094-2000, in term of its compressive strength, the quality of red clay bricks can be classified into three levels as presented in Table 2.

Table 2. The average compressive strength of bricks (SNI 15-2094-2000)

\begin{tabular}{|c|r|r|r|r|}
\hline \multirow{2}{*}{ Quality } & \multirow{2}{*}{ Class } & \multicolumn{2}{|c|}{ Fc' $^{\prime}$} & \multicolumn{1}{c|}{$\begin{array}{c}\text { Permit } \\
\text { coefficient of } \\
\text { variation }\end{array}$} \\
\cline { 3 - 4 } & & $\begin{array}{l}\text { Kg/ } \\
\mathbf{c m}^{\mathbf{2}}\end{array}$ & $\mathbf{N} / \mathbf{m m}^{2}$ & \\
\hline Grade I & 50 & 50 & 5 & $22 \%$ \\
\hline Grade II & 100 & 100 & 10 & $15 \%$ \\
\hline Grade III & 150 & 150 & 15 & $15 \%$ \\
\hline
\end{tabular}

Clay is the soil that has cohesion and plasticity. Carbonic acid and activity generated from geothermal energy will form clay during the weathering process of silica rocks. When mixed with water, the clay will produce plastic properties from the mineral particles contained in the clay [7]. On the other hand, clay production involving chemical reaction will compose groups of colloid-sized particles with tiny grain diameters of $0.002 \mathrm{~mm}$.

The manufacturing of the bricks undergoes several processes; excavating molding, drying, and high temperature- burning, which result in color changes. [6] The color changes of the burnt clay depends on the substance it contains, such as aluminum, iron, carbon, manganese, and calcium.[7]. The colors produced by iron compounds are yellowish-white, yellow, red, brown, and black. On the other hand, Limonite compounds produce brown, yellowish-white, and yellow. The red color of the clay is due to the content of hematite compounds and the green color is due to the iron silicate compounds contained in the clay.
Meanwhile, manganese compounds produce brown carbon compounds that produce blue, gray, green, or brown colors. Determining the color of bricks during burning is quite challenging [8]. Table 3 shows the approximate color change of the raw clay after the burning

Table 3 Clay color changes after the combustion process [8]

\begin{tabular}{|c|c|}
\hline Color of clay & Changes color after burning \\
\hline Red & Red or brown \\
\hline Dark yellow & Dark yellow, brown, or red \\
\hline chocolate & White or yellowish-white \\
\hline White & Red, dark yellow, or white \\
\hline Gray or black & Red \\
\hline Green & $\begin{array}{c}\text { Dark gray, early red then cream, dark } \\
\text { yellow or greenish-yellow when } \\
\text { melting }\end{array}$ \\
\hline $\begin{array}{c}\text { Red, Yellow, } \\
\text { dark gray }\end{array}$ & \begin{tabular}{c} 
War \\
\hline
\end{tabular} \\
\hline
\end{tabular}

Fig. 1 shows that the changes in the bricks before and after being burned. Before burning, the bricks have two distinct surfaces close together, while the grains have only one boundary after being burned. The driving force from the combustion is a reduction in the surface area (which means a reduction in surface energy.[10]

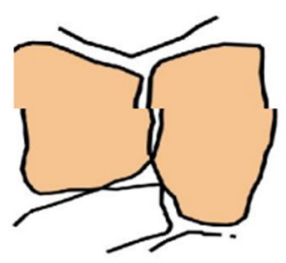

(a)

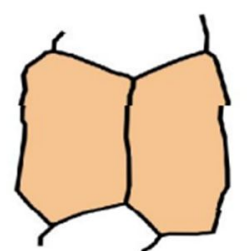

(b)
Fig. 1. (a) Bricks before burning and (b) Bricks after burning [10]

Good quality bricks are resulted from the perfect timing and temperature in the combustion. Silica crystals will re-crystallize and melt if they are at the precise temperature. If only using direct firewood without a furnace room, that temperature is impossible to be created. [9]

\section{Brick Making Process}

The stages in the brick-making process are excavation of soil or raw materials, material processing, brick formation, brick drying, brick burning, and brick cooling. The stages of brick making are as follows [6]

\subsection{Raw Material Excavation}

Excavation of brick raw materials should be carried out with less plastic soil and added with sand to prevent shrinkage. The excavation is still done manually with a hoe. After digging in the thickness of 40-50 cm on the top layer, the soil is cleaned of leaves, tree roots, plastic. After 
that, it is dug again to a depth of 1.5-2.5 meters or depending on soil conditions. The excavated soil is collected and stored in a protected place in order to break down the organisms contained in the clay. The longer the clay is stored, the more decayed it gets.

\subsection{Raw Material Processing}

When processing clay, raw materials must be mixed, which is referred to as pulverizing work. This work is still done manually by trampling the wet clay by either man power or animal power and can also be crushed by hand manually or by a tractor machine.All the mixed ingredients must be evenly mixed with the clay. Before being formed with a mold, this ready-made raw material is rested 2 to 3 days allowing the clay particles to absorb water in order to make them more stable resulting a whole shrinkage.

\subsection{Formation of Bricks}

After the raw material acquires the plastic properties in 2 to 3 days rested, it is printed with wood or glass molds according to the standard size of SNI 15-2094-1991 or SII-0021-78. So that the clay does not stick during the molding process, the wooden mold must first be soaked with water. The surface of the ground floor of the brick molding must be flat and sprinkled with rice husk ash. The first step in the brick molding process is placing the mold on the ground floor. The clay is ready to be stirred or mixed and it is then placed into the mold by pouring it, and after that, it is pressed by hand so that there are no cavities left in the mold. Next, the mold is flipped and exposed to the sun. Finally the raw bricks are then collected in a protected place to be ventilated.

\subsection{Brick Drying}

The brick drying process is still done manually using sunlight. The drying process of bricks would be better if done gradually. The raw bricks are coated with plastic to preven the direct exposure of the sunlight. The direct sunlight exposure will cause cracks on the bricks . The 1-day old bricks are then flipped. Furthermore, the dry bricks are arranged crosswise to be exposed to the wind so called fencing. This process only takes two days in a sunny weather and takes more or less a week in a cloudy or rainy weather.

\subsection{Burning Bricks}

Checking the heating and cooling temperature during the burning process is crucial. During the combustion process, the clay will undergo physical, chemical, and mineralogy changes. The process of burning bricks must be balanced with an increased temperature and a increased rate of temperature during the process. There are several stages; a. Stage of evaporation (drying). At this stage, the release of the forming water occurs up to a temperature of about $120^{\circ} \mathrm{C}$. b. Oxidation stage. At this stage, the burning of plant remains (carbon) is contained in the clay. This process takes place at a temperature of $650^{\circ} \mathrm{C}-800^{\circ} \mathrm{C}$. c. Full combustion stage. At this stage, the brick is burned until it is cooked and vitrification occurs until it becomes a solid brick. The ripening temperature varies between $920^{\circ} \mathrm{C}-1,020^{\circ} \mathrm{C}$, depending on the nature of the clay used. d. containment stage. At this stage, the temperature should be kept stable for 1-2 hours. In stages 1, 2, and 3, the rise of the temperature should be too rapid to prevent the crack in the bricks, the black color, expansion, and etc.

Factors that affect bricks during the firing process are temperature, time, particle size, surface energy, and etc. Structural physical changes are caused by a reduction in the number and size of pores, grain growth, an increase in density, and shrinkage. Clay that has a large surface area and small size will produce great strength to bind both physically and chemically to the surrounding water. Water heated to temperatures above $1000^{\circ} \mathrm{C}$ will not be easily extracted from the clay.

During the burning process, wood or rice husks can be used as a fuel. To produce good quality of bricks, they should be burned at high temperatures, and it is better to use wood as the fuel since it contains carbon elements. Selecting the proper fuel ensure the quality of the bricks. [10]

\section{Mechanical Properties of Bricks}

The mechanical properties of bricks are significant for research purposes and are also used to determine the properties and capabilities by testing and analysis.

\section{Porosity (Water absorption)}

The strong bricks will have low absorption of water and humidity. The higher the level of the absorption to water and humidity is, the poorer the quality of the bricks is. Bricks are structural elements that have hygroscopic properties, which means they easily absorb water. The acceptable water absorption for clay bricks is less than $20 \%$ [11]. The amount of porosity in a material varies from $0 \%$ to $90 \%$, depending on the type and quantity of the material. The strength of the object will increase if the porosity contained in the object is minor. On the contrary, if the porosity content in the object is significant, the strength will decrease. To calculate the porosity.[12]

$$
\begin{aligned}
& \text { Porosity }(\%)=\frac{(M b-M k)}{V b} \times \frac{1}{\rho a i r} \times 100 \% \\
& \mathrm{Mb}=\text { Wet mass }(\mathrm{g}) \\
& \mathrm{Mk}=\text { Dry mass }(\mathrm{g}) \\
& \mathrm{Vb}=\text { Volume }(\mathrm{cm} 3) \\
& \text { water }=\text { Density of water }(\mathrm{g} / \mathrm{cm} 3)
\end{aligned}
$$

\subsection{Burning Shrink}

Burning shrink is a change in dimensions or changes in the volume of the material that has been burned. Shrinkage due to changes in microstructure (grain or grain boundaries) indicates that a sintering process or heating of brick has occured.

Bricks made of clay or clay with a good burn value is considered in a number of less than $2.5 \%$ in order to 
prevent bricks with crack or any defect. The equation is used to determine the amount of burn loss [13]

Shrinkage $(\%)=\frac{\left(I_{0}-I_{1}\right)}{I_{0}} \times 100 \%$

Information,

$I_{0}=$ Length of test sample before burning $(\mathrm{cm})$

$I_{1}=$ Length of the test sample after burning $(\mathrm{cm})$

\subsection{Specific gravity}

Density is defined as mass per unit volume with the following formula.

$S G(\rho)=\frac{\operatorname{Massa}(M)}{\text { Volume }(V)}=\left(\mathrm{gr} / \mathrm{cm}^{3}\right)$

Information,

$\mathrm{M}=$ Normal mass $(\mathrm{g})$

$\mathrm{V}=$ Volume of object $(\mathrm{cm} 3)$

\subsection{Compressive strength}

The compressive strength of the red bricks needs to be measured by using a universal compression testing machine. It will assure the quality of the bricks is based on the acceptable standard. There are factors that affect the compressive strength of red bricks as follows;

- The properties of material used in the mixture

- The proportion of the material used in the mixture

- The mixing method

- The compressing method

- The hardening process

- The burning process

\section{Methodology}

To get the physical changes of the bricks due to burning using wood, 180 pieces of bricks in size of $50 \times 50 \times 50$ $\mathrm{mm}$ were used. Each treatment used 15 pieces for different treatments. The samples were divided into two combustion conditions; the condition of 2-3 bricks from the fire burning position $(\mathrm{F})$, and one brick from the burning $(\mathrm{N})$. In these two conditions, 90 samples were made, each mix using sandy soil and clay in a ratio of $0.11 .025,0.43,0.67,1.0$, and 1.50. The burning was performed for three days and two nights by using wood. Sandy soil was taken from Lubuk Alung, and clay was taken from Gunung Sarik. The image below is an example of the material used

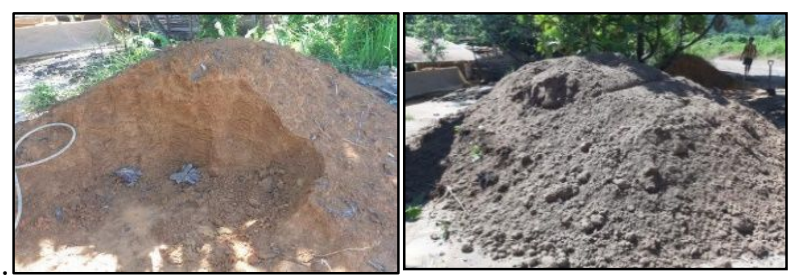

Fig. 2. Gunung Sarik clay and Lubuk Alung sandy-soil

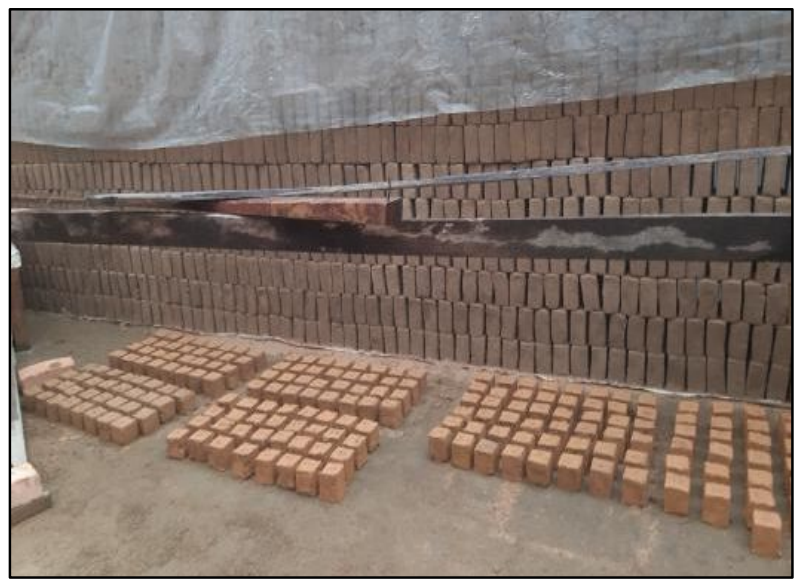

Fig. 3. Sample of $50 \times 50 \times 50 \mathrm{~mm}$ of brick on factory

Fig. 3 is an example of a test object made in a factory according to the factory's manufacturing method

After the drying process, it underwent the burning process in the firewood for 3 days and 2 nights. The image below is the temperature data during the combustion.

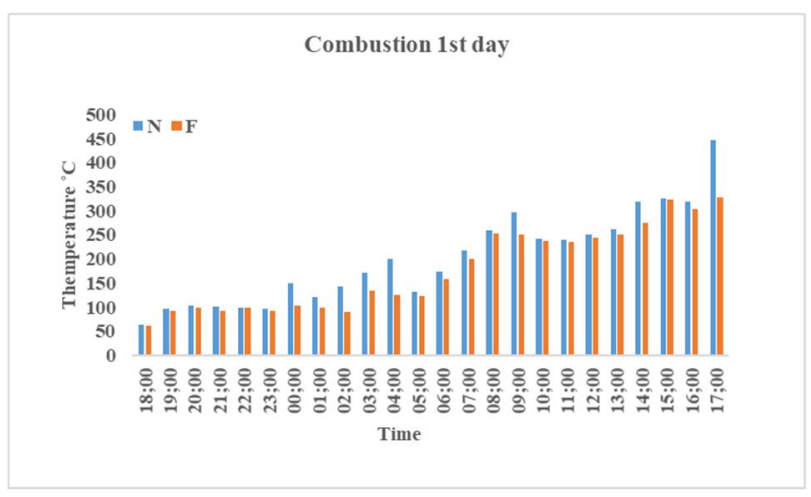

Fig. 4. The first day of combustion

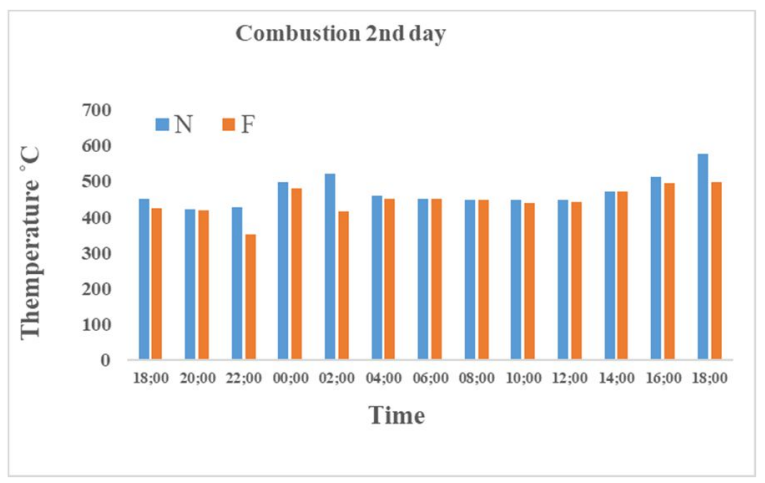

Fig. 5. The second day of combustion 


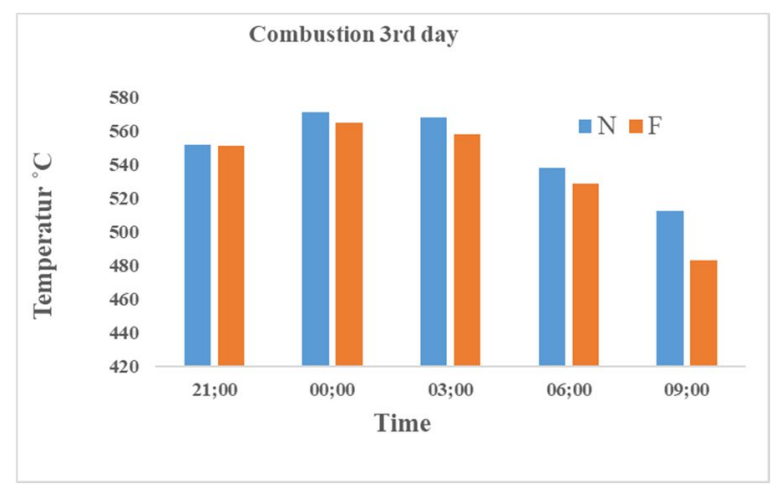

Fig. 6. The third day of combustion.

The temperatures value from low to peak temperatures in conditions near $(\mathrm{N})$ and far from the fire $(\mathrm{F})$ are shown in Figs. 4, 5, and 6. The burning temperature of the brick closest to the fire only reaches around $6000 \mathrm{C}$. It indicates that the temperature is low as in the temperature of $0-800$ 0C the bricks only undergo the drying process not the forming of the bricks themselves.

\section{Analysis and Discussion}

Fig. 7. shows the relationship between specific gravity and compressive strength, including the ratio of the sandy-soil mixture. From the test results, the compressive strength value decreases as the ratio increases. In other word, there is no significant effect to the SG either the firing of the brick is close to the firewood or the firing of the brick is far from the firewood. The compressive strength will increase as the sandy-soil ratio increases, and the effect of strength is very different for bricks that experience combustion close to the fire. It indicates that the combustion temperature dramatically affects the strength of the bricks.

Fig. 8 shows that the percentage of samples that do not experience changing in shape due to the increase of sandy soil. It indicates that the addition of sandy soil will reduce the amount of clay in one mix. The effect of adding sandy soil is that the number of bricks with a cleft is less and less cleft will occur if the heat is not in maximum rate during the process

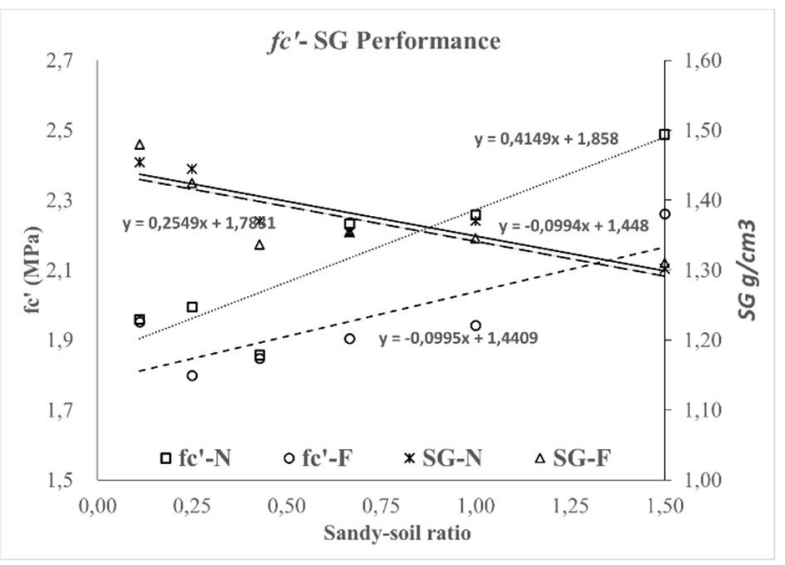

Fig. 7. Compressive strength vs Specific Gravity Performance

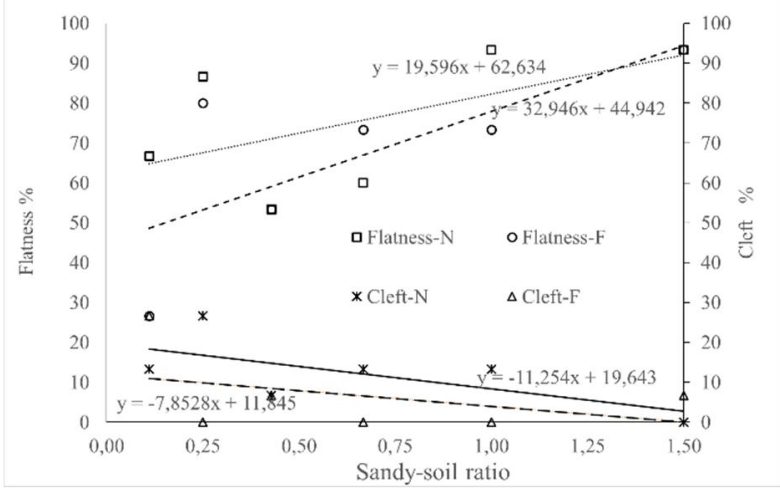

Fig. 8. Flatness and cleft performance of brick

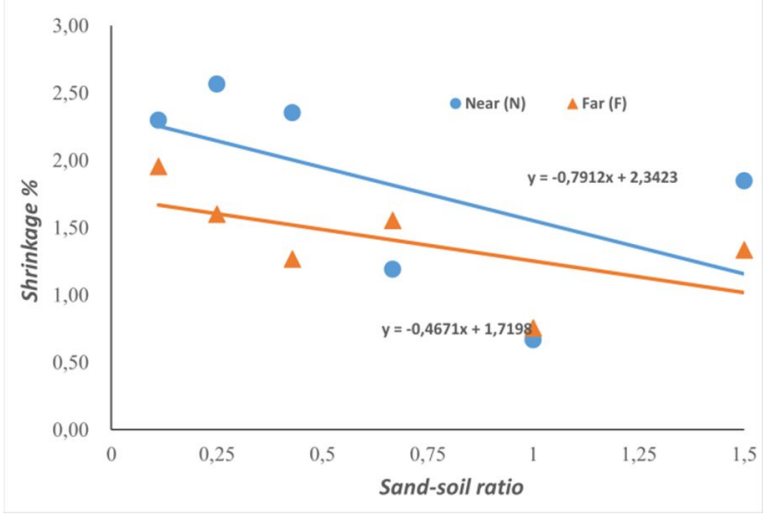

Fig. 9. Shrinkage percentages performance

Fig. 9 shows that the higher the sandy-clay ratio is, the less shrinkage occurs. However, the higher the amount of sandy clay used, the less the function of the clay, so the amount of sandy clay needs to be limited. From this research, the sandy-clay ratio is acceptable around 0.250.5 . However, this highly depends on the temperature of the manufacturing and combustion processes. The figure 9 also shows that the bricks at that stage only undergo the drying process.

\section{Conclusion}

Physical changes due to burning using wood will give effect to the quality of the brick. Moreover, burning the bricks closed to firewood or not will also give impact to the brick quality. The addition of sandy soil in the brick mixture will increase the flatness of the bricks and it will reduce the cleft and shrinkage of the bricks.

The authors would like to thank Kemenristekdikti for the financial support through the PDUPT scheme by contract number 002/27.O10.5/PN/VII/2021.

\section{References}

1. M. Ridwan, I. Yoshitake, A. Nassif, Proposal of Design Formulae for Equivalent Elasticity of Masonry Structures Made with Bricks of Low 
Modulus", Advances in Civil Engineering, 1-11 (2017)

2. M. Ridwan, I. Yoshitake, A. Nassif, Twodimensional fictitious truss method for estimation of out-of-plane strength of masonry walls",Construction and Building Materials, 152, 24-38 (2017)

3. M. Ridwan, R. Kurniawan, Agus, An evaluation of mechanical properties of clay brick for masonry wall in Indonesia, MATEC Web of Conferences, 215, 01034 (2018)

4. G. Pruthvi Raj, M. Ravula, K. Subramaniam, Failure in Clay Brick Masonry with Soft Brick under Compression: Experimental Investigation and Numerical Simulation, Key Engineering Materials, 747, 472-479 (2017)

5. G. Kirkelund, L. Skevi, L. Ottosen, Electrodialytically treated MSWI fly ash use in clay bricks, Construction and Building Materials, 254, 119286, (2020).

6. M. Erna Hastuti, "Effect of Combustion Temperature and Addition of Ash on Bricks Quality", Journal of Neutrino (2012).

7. M. Wilson, A Handbook Of Determinative Methods In Clay Mineralogy. Glasgow: Blackie (1987).
8. 8. M. Maulani, M. Mulyadi And S. Syakri, "Application Design To Identify Compressive Strength Of Bricks Based On Color Based Image Processing Using Statistical Feature Extraction Methods", Jurnal Infomedia,. 1, 1 (2016)

9. 9. I. Nur, "Improving the Quality of Clay as Raw Material for Making Bricks in Bukaka Village, Bone Regency, South Sulawesi", Correct Journal: Applied Technology Journal For Community Engagement And Services, 3 (2), 135-146 (2020)

10. 10. S. Pramono, "Waste as Raw Material for Brick Making", In Proceedings of Semnas Entrepreneurship, 275-294 (2014).

11. 11. A. Chandra, D. Djamas And R. Ramli, "The Effect of Annealing Temperature on Physical Properties of Natural Fiber Waste Bricks", Sainstek: Journal of Science and Technology, 8 (2), 150 (2017).

12. 12. V. Vlack And L. H, Materials Science and Technology. Jakarta: Erlangga (1992).

13. 13. Suwardono, Knowing the Making of Brick, Tile, and Glazed Tile, Cv. Yrama Widya, Bandung (2002) 